18-20 December, 2020

Oxford, United Kingdom $11^{\text {th }}$ International Conference on

Humanities, Psychology \& Social Sciences

\title{
Contradictions in public policy in relation to victims of trafficking within UK"
}

\author{
Danah Nasrallah \\ Bradford Uni
}

\begin{abstract}
This paper aims to analyze a serious crime named trafficking that has affected millions of people all over the world. The paper discusses its major elements, the various factors, its forms, and the targets. It explains that trafficking is described as a highly organized crime, and the traffickers work in big networks of sex-trade, forced labor, forced prostitution, or other forms of bigger crimes including money laundering, etc. That has extended to their own countries and abroad as well. The paper primarily focuses on trafficking and the system to deal with victims of crime in the United Kingdom. The paper mainly aims to draw attention to the situation of victims, actions taken against trafficking or improvements did so far in this area against traffickers, and for the protection of victims of modern slavery. Thereafter, it seeks to highlight the challenges faced by the victims of the crimes and the failures of the system to bring up solutions to overcome the crime. By analyzing the current situation, concerns, improvements done so far, the paper point out the gaps that need to be filled for the benefits of the victims of modern slavery. The paper intends to draw attention to every concern and challenges that are being faced by the survivors of crime, even after they are back in society. The current criminal justice system fails to deal with the issues that are the fate of the victimsand the government should re-build, reform, and improve its system and provide appropriate support to them, shelters, and provision of medical and health care so they can trust again on authorities, come out of the traumatic situation, integrated into society and provide effective evidence against criminals.
\end{abstract}

Keywords: human trafficking -modren act law-victims -immigration -justice. 